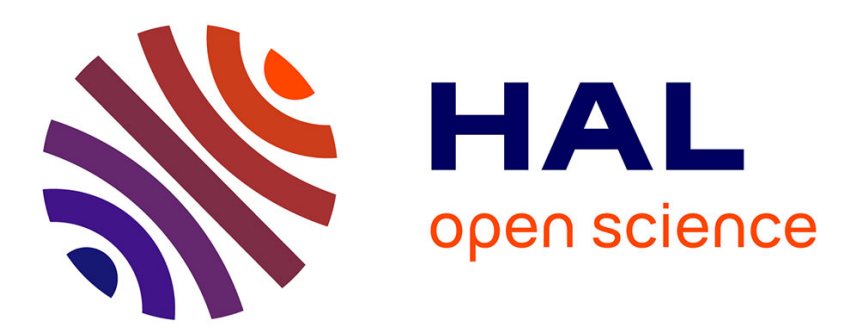

\title{
Seasonal effect of the exotic invasive plant Solidago gigantea on soil $\mathrm{pH}$ and $\mathrm{P}$ fractions
}

C. Herr, Lydie Chapuis Lardy, N. Dassonville, S. Vanderhoeven, P. Meerts

\section{To cite this version:}

C. Herr, Lydie Chapuis Lardy, N. Dassonville, S. Vanderhoeven, P. Meerts. Seasonal effect of the exotic invasive plant Solidago gigantea on soil $\mathrm{pH}$ and $\mathrm{P}$ fractions. Journal of Plant Nutrition and Soil Science, 2007, 170 (6), pp.729-738. 10.1002/jpln.200625190 . ird-00293112

\section{HAL Id: ird-00293112 \\ https://hal.ird.fr/ird-00293112}

Submitted on 3 Jul 2008

HAL is a multi-disciplinary open access archive for the deposit and dissemination of scientific research documents, whether they are published or not. The documents may come from teaching and research institutions in France or abroad, or from public or private research centers.
L'archive ouverte pluridisciplinaire HAL, est destinée au dépôt et à la diffusion de documents scientifiques de niveau recherche, publiés ou non, émanant des établissements d'enseignement et de recherche français ou étrangers, des laboratoires publics ou privés. 


\section{Dernière version d'auteur avant publication}

Herr C., Chapuis-Lardy L., Dassonville N., Vanderhoeven S., Meerts P. Seasonal effect of the exotic invasive plant Solidago gigantea on soil pH and P fractions. Journal of Plant Nutrition and Soil Science Zeitschrift fur Pflanzenernahrung und Bodenkunde, 2007, 170 (6), p. 729-738.

\section{Short running title}

Seasonal soil P after Solidago gigantea invasion

\section{Corresponding author}

Dr. L. Chapuis-Lardy

SeqBio, Carbon Sequestration and Soil Biota group, Institut de Recherche pour le Développement, BP 434, Ambatoroka, 101 Antananarivo, Madagascar

Phone / fax numbers: +261202233098 / +2612022369 82

E-mail address: lydie.lardy@ird.fr 


\section{Seasonal effect of the exotic invasive plant Solidago gigantea on soil $\mathrm{pH}$ and phosphorus}

fractions

Cécile Herr ${ }^{1}$, Lydie Chapuis-Lardy ${ }^{1,2 *}$, Nicolas Dassonville ${ }^{1}$, Sonia Vanderhoeven ${ }^{1,3}$, and Pierre Meerts ${ }^{1}$

${ }^{1}$ Laboratory of Plant Genetics and Ecology, Université Libre de Bruxelles, Chaussée de Wavre 1850, B-1160 Brussels, Belgium

${ }^{2}$ Current address: SeqBio, Carbon Sequestration and Soil Biota group, Institut de Recherche pour le Développement, BP 434, 101 Antananarivo, Madagascar

${ }^{3}$ Current address: Laboratory of Ecology, Gembloux Agricultural University, Passage des Déportés 2, B-5030 Gembloux, Belgium

*Correspondence: Dr. Lydie Chapuis-Lardy; e-mail: lydie.lardy@ird.fr

Key words: Exotic species effects / early goldenrod / soil-plant P cycling / soil phosphorus availability / microbial P biomass / phosphomonoesterase.

\section{Summary}

Invasions by alien plants can alter biogeochemical cycles in recipient ecosystems. We test if Early goldenrod (Solidago gigantea) alters phosphorus fractions. To that end, we compare invaded plots and adjacent, uninvaded resident vegetation for specific fractions of organic and inorganic P, phosphomonoesterase (PME) activity in topsoil, and immobilization of $\mathrm{P}$ in above- and belowground organs and in soil microbial biomass. Invaded plots had lower soil $\mathrm{pH}$ and $20-30 \%$ higher labile phosphorus fractions (resin-Pi, bicarb-Pi, $\mathrm{NaOH}-\mathrm{Pi}$ ), and the difference was consistent across seasons. There was no difference in microbial P. Alkaline PME activity was 30\% lower in topsoil invaded plots. Annual P uptake in aboveground phytomass was not markedly higher in Solidago. In contrast, $\mathrm{P}$ in belowground organs steadily increased in autumn in invaded plots, due to both increased biomass and increased $\mathrm{P}$

Based on a poster presentation at the $4^{\text {th }}$ International Conference on Biological Invasions NEOBIOTA - From Ecology to Conservation, September 27-29, 2006, Vienne, Austria. 
concentrations. This indicated higher net P immobilization in Solidago, far in excess of both resorption from senescing shoots and $\mathrm{P}$ requirements for aboveground biomass in subsequent year. Higher turnover rates of $\mathrm{P}$ in belowground organs and mobilization of sparingly soluble $\mathrm{P}$ forms through rhizosphere acidification may be involved in the observed differences in soil P status between invaded and uninvaded plots.

\section{Introduction}

Biogeochemical cycling of nutrients is influenced by the species composition of plant communities (Evans et al., 2001; Vitousek et al., 1987). Invasions by exotic plant species may result in dramatic changes in the structure of plant communities (Tyser and Key, 1988). In some cases, exotic invasive plants are able to spread rapidly and build up monospecific stands in their new habitats. In addition to their effects on community structure, invasive plants can alter ecosystem function (Vitousek, 1990; Ehrenfeld et al., 2001). Thus, impacts of invasive plants on soil C and $\mathrm{N}$ were demonstrated. In general, exotic invasive species have higher net primary productivity and higher turnover rates of $\mathrm{C}$ and $\mathrm{N}$, but the opposite pattern was also found (Ehrenfeld, 2003). These impacts are also mediated by alterations in soil microbial communities (Hooper and Vitousek, 1998; Kourtev et al., 2002).

In addition to $\mathrm{N}, \mathrm{P}$ is the second most limiting mineral nutrient to plants in natural habitats. Impacts of invasive species on $\mathrm{P}$ and other nutrients were rarely examined. Thus, increased soil $\mathrm{P}$ fractions were found under the canopy of invasive nitrogen-fixing species (Witkowski and Mitchell, 1987) and of the crucifer Lepidium latifolium (Blank and Young, 2002). Plant species effects on soil phosphorus can be mediated by various mechanisms including alterations of rhizosphere $\mathrm{pH}$, production of phosphoesterases, symbiotic interactions, and mobilization of sparingly soluble P forms by root exudates (Hinsinger, 2001 and references therein).

Early Goldenrod (Solidago gigantea), introduced from North America as an ornamental species, has spread rapidly in Europe, becoming one of the most widespread alien invasive species (Jakobs et al., 2004). Recently, Güsewell et al. (2005) failed to show a significant impact of invasion by Early Goldenrod (Solidago gigantea) on total soil phosphorus in Swiss wetlands. Chapuis-Lardy et al. (2006) did not also find impact on total soil P but found increased concentrations of readily available inorganic P in topsoil under S. gigantea, possibly 
due to increased phosphatase activity. However, in this study soil P was sampled on a single date and was determined on dried soil samples. Seasonal variation of soil labile P fractions and phosphatase activity may be quite large (Chen et al., 2003; Grierson and Adams, 2000; Krämer and Green, 2000). The possibility also exists that impacts on soil P vary throughout the year, due to phenological differences between Early Goldenrod and native vegetation. Finally, in order to better understand the mechanisms of the impacts, other important $\mathrm{P}$ fractions need to be quantified, including $\mathrm{P}$ in plant tissues and litter and soil microbial $\mathrm{P}$.

In this study, in an effort to better understand the mechanisms by which Early Goldenrod may affect soil $\mathrm{P}$, we examine seasonal variation of labile inorganic and organic soil $\mathrm{P}$ fractions, microbial P, and phosphomonoesterase activity. All measurements were performed on fresh soil samples. In addition, $\mathrm{P}$ in standing biomass (above- and belowground) was also assessed.

\section{Materials and methods}

\subsection{Invasive plant}

Solidago gigantea (Asteraceae) (Early Goldenrod) is a geophytic rhizomatous perennial up 2 $\mathrm{m}$ in height. Due to clonal growth, the species can form dense, monospecific stands (Jakobs et al., 2004). Early goldenrod is native to North America and was introduced to Europe in the nineteenth century as an ornamental species. In Europe, goldenrod species apparently don't suffer from herbivory and show increased vigor and competitive ability compared to populations from the native range (Jakobs et al., 2004).

\subsection{Study site}

The study site is located at Kraainem, a few km in the North-East of the city of Brussels (Belgium). S. gigantea has established there for more than 20 years in an abandoned cultivated field. It forms dense, monospecific stands, ranging in size from a few to ca. $50 \mathrm{~m}^{2}$, surrounded by native, herbaceous vegetation. Invaded patches are still extending. Native vegetation is a dense, mesic grassland $0.5-1 \mathrm{~m}$ in height. The most abundant species are: Achillea millefolium, Agrostis stolonifera, Carex flacca, Cirsium arvense, C. palustre, Daucus carota, Festuca rubra, Holcus lanatus, Leucanthemum vulgare, Plantago lanceolata, Pulicaria dysenterica, Ranunculus repens, Senecio jacobaea. In contrast to the resident vegetation, all aboveground organs of Early Goldenrod die off in November and are completely replaced in spring. According to the FAO classification, the soil was an eutric 
regosol with anthropic origin (cf. deep cultivation) (FAO/UNESCO, 1990). A preliminary soil auger investigation suggested a relatively homogenous soil cover in the whole area (i.e. no apparent topsoil difference between invaded stands and uninvaded zones). Selected characteristics of this silty loam soil were given in Table 1.

Table 1: Selected properties of the topsoil $(0-10 \mathrm{~cm}$ in depth, $\mathrm{n}=6)$ in invaded and uninvaded stands

\begin{tabular}{|c|c|c|c|}
\hline & Uninvaded & Invaded & $P(t \text {-test })^{\mathrm{b}}$ \\
\hline $\mathrm{pH}$ & 6.5 & 5.9 & $*$ \\
\hline $\operatorname{CEC}^{\mathrm{a}}\left(\mathrm{cmol}_{\mathrm{c}} \mathrm{kg}^{-1}\right)$ & 8.3 & 8.4 & ns \\
\hline $\mathrm{K}^{\mathrm{a}}\left(\mathrm{cmol}_{\mathrm{C}} \mathrm{kg}^{-1}\right)$ & 68.2 & 97.9 & ns \\
\hline $\mathrm{Mg}^{\mathrm{a}}\left(\mathrm{cmol}_{\mathrm{C}} \mathrm{kg}^{-1}\right)$ & 109.9 & 126.0 & ns \\
\hline $\mathrm{P}^{\mathrm{a}}\left(\mathrm{mg} \mathrm{kg}^{-1}\right)$ & 2.6 & 4.6 & $*$ \\
\hline Total C (\%) & 1.48 & 1.80 & ns \\
\hline Total N (\%) & 0.135 & 0.150 & ns \\
\hline Clays (\%) & 2.45 & 2.43 & ns \\
\hline Bulk density $\left(\mathrm{g} \mathrm{cm}^{-3}\right)$ & 1.21 & 1.13 & $*$ \\
\hline
\end{tabular}

Invaded plots have lower $\mathrm{pH}$ and bulk density, and higher concentrations of ammoniumacetate extractable $\mathrm{P}$ (Table 1). There is no significant difference in other elements concentration or in clay content between the soils under invaded and native, uninvaded vegetation.

\subsection{Soil sampling}

Soil samples were collected at five dates (July and September 2004, January, March and May 2005) from ten $1 \mathrm{~m}^{2}$-plots (5 plots in uninvaded vegetation and 5 plots within invaded stands). Plots in uninvaded vegetation were located randomly and were at least $10 \mathrm{~m}$ apart from each other. Invaded plots were located within the different largest Solidago stands, where the density of Solidago shoots was highest. In each plot, 6 soil cores were collected $(0-10 \mathrm{~cm}$ in depth, diameter: $4 \mathrm{~cm}$; litter discarded) and pooled into a single bulk sample. Sampling was restricted to $10 \mathrm{~cm}$ in depth because phosphatase activity and microbial $\mathrm{P}$ are most elevated in that soil layer (Chen et al., 2003; Spears et al., 2001; Chen, 2003; Grierson and Adams, 2000). Fresh soil samples were used on account of the fact that air-drying may alter $P$ 
chemical speciation, microbial immobilization and phosphatase activity (Bartlett and James, 1980; Brookes et al., 1982; Turner et al., 2002a). Fresh soil samples were sieved (4 mm mesh) and root fragments were manually removed. Analyses were performed generally within $48 \mathrm{~h}$ of collection. Relative moisture content was determined by oven-drying $\left(105^{\circ} \mathrm{C}\right)$.

\subsection{Plant sampling}

Above- and below-ground vegetation samples were collected at three dates corresponding to contrasted phenological states: (i) at the peak of aboveground biomass (August 2004), (ii) after the start of senescence (November 2004) and (iii) during aboveground biomass production (May 2005). Vegetation collection plots (i.e. 4 in invaded and 4 in uninvaded vegetation; $0.5 \mathrm{~m} \times 0.5 \mathrm{~m}$ for shoots and $0.3 \times 0.3 \mathrm{~m}$ for roots) were located close to the corresponding soil sampling plots ( $<1 \mathrm{~m}$ apart). Aboveground biomass of Solidago was divided in three parts: living leaves, living stems, and litter. Litter comprises organic debris on the ground and standing dead shoots from previous year. For the uninvaded vegetation, which is dominated by grasses, sorting living and dead organs was practically not feasible due to gradual senescence of grass leaves and all aboveground parts were thus pooled. Belowground organs were excavated (depth: 0-20 cm) in August and November; no roots collection in May 2005. The soil samples were sieved under running tapwater and rhizomes and roots were carefully separated from the mineral fraction with a $2 \mathrm{~mm}$ sieve. Plant samples were ovendried until constant weight at $50^{\circ} \mathrm{C}$, and ground $(<0.12 \mathrm{~mm})$ before analysis.

\subsection{Soil and plant analyses}

\subsubsection{Soil analyses}

Soil $\mathrm{pH}$ was measured with a glass electrode on a soil-water stiff paste (1:1 soil:distilled water ratio).

All $\mathrm{P}$ forms were assessed on fresh soil sample (sieved at $4 \mathrm{~mm}$ ). Different extraction methods were used to assess specific fractions of phosphorus with contrasting bioavailability. Anion exchange resins were used to assess readily available P-forms. Methods for determining inorganic P extractable by anion exchange resins follow Kouno et al. (1995). Three grams of soil samples were shaken in $30 \mathrm{~mL}$ demineralised water in presence of 3 strips (60 x $10 \mathrm{~mm}$ ) of anion exchangeable resins (B.D.H. Chemicals Ltd, Poole, UK) for 16 hrs. 
Resin strips were rinsed and shaken in $30 \mathrm{~mL} \mathrm{HCl} 0.5 \mathrm{M}$ for $1 \mathrm{hr}$ and $\mathrm{P}$ was determined by colorimetry (John, 1970). Sodium bicarbonate extractable fractions also comprise P that is considered as bioavailable in the short term. Five grams of fresh soil was shaken in $100 \mathrm{~mL}$ $\mathrm{NaHCO}_{3}$ (0.5 M; pH 8.5; Olsen and Sommers, 1982) for $30 \mathrm{~min}$. Sodium hydroxide extractable fraction comprises $\mathrm{P}$ forms that are considered as more slowly available. One gram of soil was shaken in $30 \mathrm{~mL} \mathrm{NaOH}(0.1 \mathrm{M})$ for 16 hrs (Bowman and Cole, 1978). Bicarb-P and NaOH-P extracts were acidified and diluted for determination of inorganic $\mathrm{P}$ (bicarb-Pi and $\mathrm{NaOH}-\mathrm{Pi}$, respectively) as recommended by Tiessen and Moir (1993). Total phosphorus (Ptot) was also determined on the same extracts by oxidation in the autoclave in presence of ammonium persulfate (Tiessen and Moir, 1993). Organic phosphorus (bicarb-Po and $\mathrm{Na} \mathrm{OH}-\mathrm{Po}$, respectively) was determined as $(\mathrm{Po}=\mathrm{Ptot}-\mathrm{Pi})$. $\mathrm{P}$ was determined colorimetrically in all extracts by the ascorbic acid-ammonium molybdate method (John, 1970).

A fumigation-extraction method was applied to determine microbially immobilized $\mathrm{P}$ (McLaughlin and Alston, 1986). Each soil sample was divided into 3 subsamples that were treated in parallel. In subsample A, Pi was extracted in $100 \mathrm{~mL}$ sodium bicarbonate $(0.5 \mathrm{M}$, $\mathrm{pH}$ 8.5) for $30 \mathrm{~min}$. Subsample B was subjected to fumigation using liquid chloroform for 36 hrs, followed by bicarbonate extraction after complete evaporation of chloroform. A correction coefficient $\mathrm{Kp}\left(0.40\right.$ at $25^{\circ} \mathrm{C}$; Brookes et al., 1982) was applied to account for incomplete recovery of microbial Po. Subsample C was extracted in sodium bicarbonate after addition of inorganic P $(125 \mu \mathrm{g})$. This served to assess the magnitude of Pi sorption, expressed as the recovery coefficient R. All extracts were acidified and diluted (Tiessen and Moir, 1993) and $\mathrm{P}$ was determined colorimetrically as specified hereabove. All measurements were replicated thrice. Microbial biomass P was finally calculated as [(B-A) x 100 /(R x Kp)] (Kouno et al., 1995). This analysis was not performed for the July samples.

Phophomonoesterases (PME) activity was determined by the para-nitrophenyl phosphate tetrahydrate (pNPP) method (Tabatabai, 1982). A fresh soil sample was incubated with pNPP at $37^{\circ} \mathrm{C}$ and $\mathrm{pH} 6.5$ (acid phosphatases) or $\mathrm{pH} 11$ (alkaline phosphatases). Reaction was stopped with $\mathrm{NaOH} 0.5 \mathrm{M}$ and $\mathrm{CaCl}_{2} 0.5 \mathrm{M}$. After filtration, the product of the reaction (pNP, para-nitrophenol) was determined colorimetrically at $410 \mathrm{~nm}$. Each sample was replicated thrice. A blank was included to correct for non enzymatic hydrolysis. Enzymatic activities are expressed as $\mu \mathrm{g}$ pNP g soil ${ }^{-1} \mathrm{~h}^{-1}$. Phosphomonoesterases (PME) are enzymes involved in hydrolysis of phosphomonoesters and are thus most important in mineralization of organic phosphorus. Acid phosphatases (ac-PME) are most abundant in acid soils (Tabatabai, 1982) 
and are produced by plant roots, microorganisms and pedofauna. Alkaline phosphatases (alkPME) are most abundant in neutral soil and are produced by soil bacteria, fungi and animals only (Krämer and Green, 2000).

\subsubsection{Phytomass analyses}

Plant samples were ashed in a muffle furnace at $550^{\circ} \mathrm{C}$ for $8 \mathrm{hrs}$. Ashes were dissolved in concentrated $\mathrm{HCl}$ and $\mathrm{P}$ was determined by ICP-OES (Varian Vista MPX).

\subsection{Calculation of pools and fluxes}

Soil P pools were calculated based on measurements of soil bulk density in invaded and uninvaded patches.

The amount of $\mathrm{P}$ that is resorbed in autumn from senescing shoots of Solidago was estimated as follows: [(P concentration at the peak of biomass $-\mathrm{P}$ concentration in senesced shoots $) \times$ aboveground biomass]. For the uninvaded vegetation, it was not possible to calculate resorption because senesced and living organs could not be separated due to gradual senescence of grass leaves. Aerts (1996) estimated average P resorption efficiency of grasses as $71.6 \%$. This figure was used to calculate a rough estimation of annual $\mathrm{P}$ resorption in the uninvaded vegetation. Phytomass harvested in August in the uninvaded vegetation mostly consists of living materials (pers. obs.).

$\mathrm{P}$ loss in root litter could not be measured directly, because belowground organs were collected at only two dates (August and November) and no attempt was made to separate living and dead roots. As Solidago patches in the studied sites have more than 15 years and vegetation samples were collected in their centre, i.e. where shoot density was highest, we assume that standing biomass has reached a steady state (i.e. no net biomass increase from year to year). Under this assumption, $\mathrm{P}$ losses in root litter can be estimated based on seasonal variation in the mass of belowground organs: (Highest value of belowground $\mathrm{P}$ stock, November) - (lowest value of belowground P stock, August).

\subsection{Data analysis}

The results were expressed as arithmetic means with standard deviations. The data were analyzed by two-way analysis of variance with date and invasion as main fixed effects. Data were log-transformed when necessary to meet assumptions of analysis of variance. In this 
analysis, a significant date effect indicates seasonal variation, a significant invasion effect indicates significant difference between invaded and uninvaded plots and a significant date $\mathrm{x}$ invasion interaction indicates that the difference between invaded and uninvaded plots changes with time. All statistical analyses were performed with Statistica software (StatSoft, Inc.).

\section{Results}

\subsection{Soil parameters}

\subsubsection{Soil pH}

Soil pH was consistently lower in invaded plots at all dates (annual mean for invaded: 5.94, uninvaded: 6.36). Seasonal variation was not significant in spite of slightly lower values in July compared to January. Date x invasion interaction was also not significant (Table 2).

Table 2: Two-way analyses of variance of seasonal variation of soil $\mathrm{pH}$, soil $\mathrm{P}$ fractions, soil phosphatase activity in plots invaded by Early Goldenrod and adjacent, uninvaded plots. Degree of freedom (df), mean squares and significance levels. $* * * P<0.001$, ** $P<0.01$, * $P<0.05$, ns not significant.

\begin{tabular}{ccccc}
\hline & $\begin{array}{c}\text { Invasion } \\
(\mathrm{df}=1)\end{array}$ & $\begin{array}{c}\text { Date } \\
(\mathrm{df}=4)\end{array}$ & $\begin{array}{c}\text { Date*Invasion } \\
(\mathrm{df}=4)\end{array}$ & $\begin{array}{c}\text { Error } \\
(\mathrm{df}=41)\end{array}$ \\
\hline $\mathrm{pH}$ & $2.31^{* * *}$ & $0.26 \mathrm{~ns}$ & $0.136 \mathrm{~ns}$ & $0.177 \mathrm{~ns}$ \\
Resin-P & $0.20^{* * *}$ & $0.010 \mathrm{~ns}$ & $0.013 \mathrm{~ns}$ & $0.0122 \mathrm{~ns}$ \\
Bicarb-Pi & $0.26^{* * *}$ & $0.11^{* * *}$ & $0.0075 \mathrm{~ns}$ & $0.015 \mathrm{~ns}$ \\
Bicarb-Po & $0.036 \mathrm{~ns}$ & $0.25^{* * *}$ & $0.028 \mathrm{~ns}$ & $0.018 \mathrm{~ns}$ \\
NaOH-Pi & $0.37^{* * *}$ & $0.022 \mathrm{~ns}$ & $0.0094 \mathrm{~ns}$ & $0.019 \mathrm{~ns}$ \\
NaOH-Po & $0.024 \mathrm{~ns}$ & $0.22^{* * *}$ & $0.0038 \mathrm{~ns}$ & $0.0127 \mathrm{~ns}$ \\
Microbial P & $0.0016 \mathrm{~ns}$ & $1.015^{* * *}$ & $0.0063 \mathrm{~ns}$ & $0.135 \mathrm{~ns}$ \\
Ac-PME & $0.017 \mathrm{~ns}$ & $0.12^{* * *}$ & $0.0029 \mathrm{~ns}$ & $0.0103 \mathrm{~ns}$ \\
Alk-PME & $0.055^{* * *}$ & $0.22^{* * *}$ & $0.0066 \mathrm{~ns}$ & $0.0236 \mathrm{~ns}$ \\
\hline
\end{tabular}

\subsubsection{Soil phosphorus fractions}


Resin-Pi was systematically higher in invaded plots at all dates (Figure 1) (annual mean for invaded: 6.4, uninvaded: $4.6 \mathrm{mg} \mathrm{P}$ kg dry soil ${ }^{-1}$ ). The difference tended to be larger in summer (3.5 mg P kg dry soil ${ }^{-1}$ ) compared to winter (1 mg $\mathrm{P} \mathrm{kg}$ dry soil $\left.{ }^{-1}\right)$, but neither date nor date $\mathrm{x}$ invasion interaction were significant (Table 2).

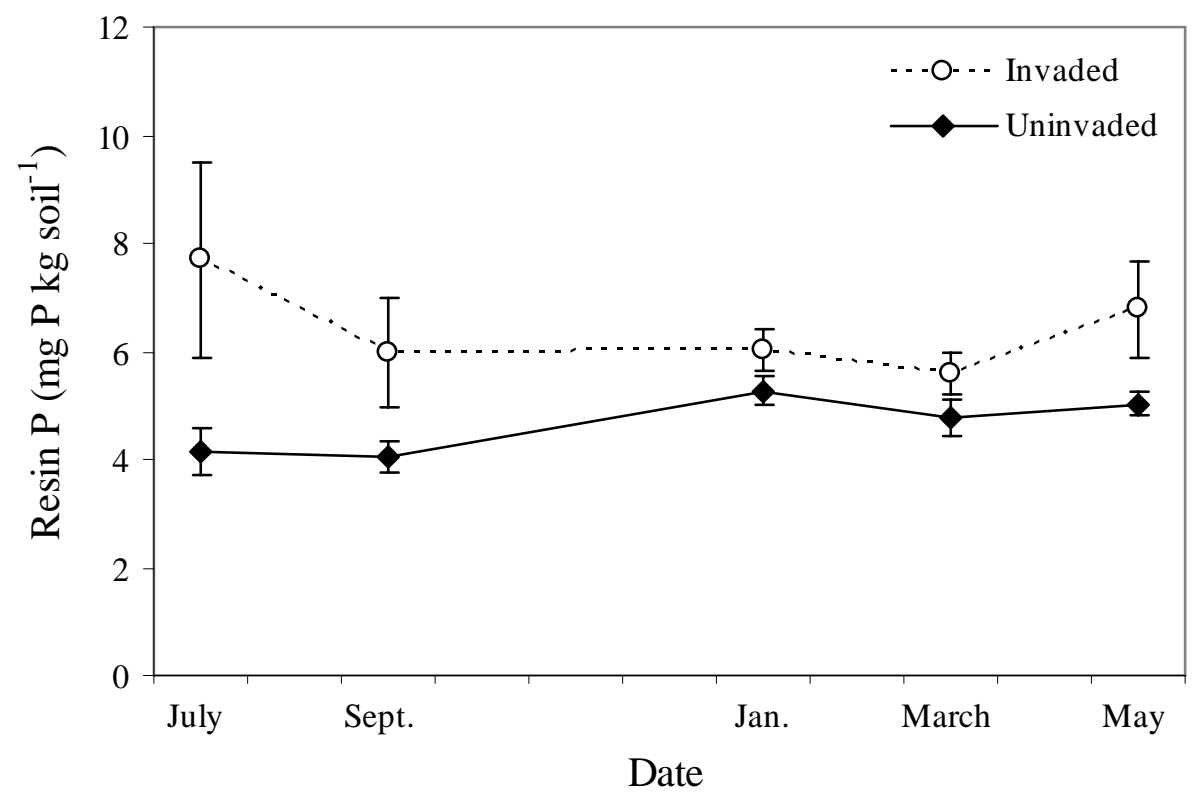

Figure 1: Seasonal variation of soil resin-Pi $(0-10 \mathrm{~cm})$ in plots invaded by early Goldenrod and adjacent, uninvaded plots. Means $(n=6)$ and standard deviations.

Bicarb-Pi was markedly higher in invaded plots (annual mean for invaded: $13.7 \mathrm{mg} \mathrm{P}$ kg dry soil $^{-1}$; uninvaded: $10.1 \mathrm{mg} \mathrm{P} \mathrm{kg} \mathrm{dry} \mathrm{soil}{ }^{-1}$ ) (Figure 2). Seasonal variation was significant $(P<0.001)$, with markedly higher values in winter compared to summer, but the date $\mathrm{x}$ invasion interaction was not significant (Table 2). Bicarb-Po did not differ between invaded and uninvaded plots (annual mean for invaded: $7.8 \mathrm{mg} \mathrm{P}$ kg dry soil ${ }^{-1}$; uninvaded: $7.0 \mathrm{mg} \mathrm{P}$ kg dry soil ${ }^{-1}$ ) (Figure 2).

Seasonal variation was significant $(P<0.001)$, with highest and lowest values in May and January, respectively. Date x invasion interaction was not significant (Table 2). NaOH-Pi was systematically higher in invaded compared to uninvaded plots (annual mean for invaded: 44.8 mg P kg dry soil ${ }^{-1}$; uninvaded: $30.1 \mathrm{mg} \mathrm{P} \mathrm{kg} \mathrm{dry} \mathrm{soil}^{-1}$ ) (Figure 2). Seasonal variation and date $\mathrm{x}$ invasion effects were not significant (Table 2). NaOH-Po had slightly higher values in invaded stands, but the difference was not significant (annual mean: invaded: $50.0 \mathrm{mg} \mathrm{P} \mathrm{kg}$ dry soil ${ }^{-1}$; uninvaded: $45.8 \mathrm{mg} \mathrm{P}$ kg dry soil $^{-1}$; $P>0.05$ ) (Figure 2). The date effect was significant $(P<0.001)$, with the lowest and the highest values in July and May, respectively (Table 2). 

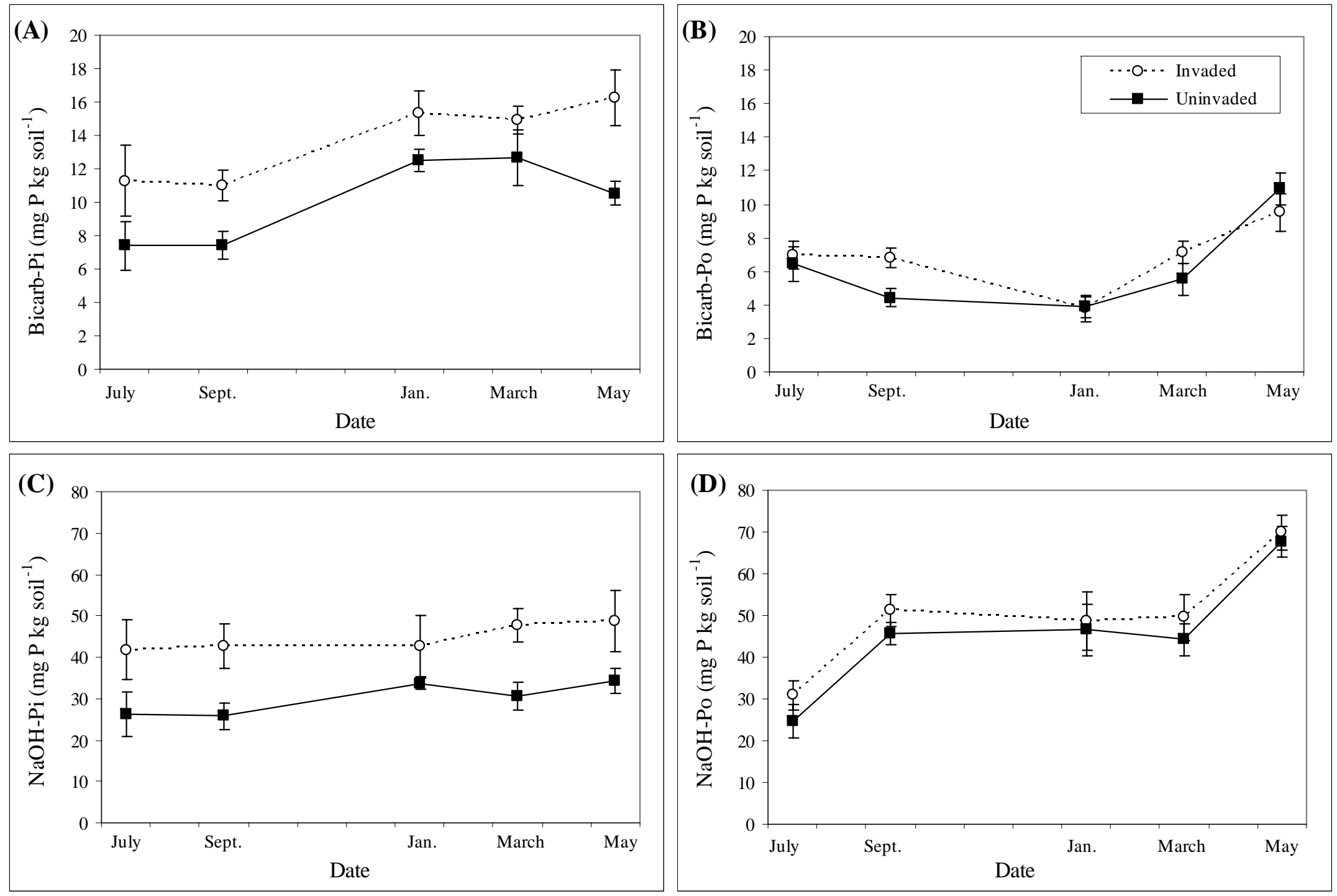

Figure 2: Seasonal variation of different soil $\mathrm{P}$ fractions $(0-10 \mathrm{~cm})$ in plots invaded by early Goldenrod and adjacent, uninvaded plots. (A) bicarb-Pi, (B) bicarb-Po, (C) NaOH-Pi, (D) NaOH-Po. Means (n=6) and standard deviations. 


\subsubsection{PME activities}

Both ac-PME and alk-PME activities were highest in July and steadily decreased from summer to the end of winter (Figure 3). Ac-PME activity was generally somewhat higher in invaded stands, but the difference was not significant (annual mean for invaded: $222.4 \mu \mathrm{g}$ pNP g soil ${ }^{-1} \mathrm{~h}^{-1}$, uninvaded: $197.9 \mu \mathrm{g}$ pNP g soil ${ }^{-1} \mathrm{~h}^{-1}$ ). Alk-PME activity was about 50\% lower in invaded stands at all dates, and the difference was highly significant (annual mean for invaded 124.1 $\mu \mathrm{g}$ pNP g soil ${ }^{-1} \mathrm{~h}^{-1}$, uninvaded: 176.4 $\mu$ g pNP g soil ${ }^{-1} \mathrm{~h}^{-1} ; \mathrm{P}<0.001$ ) (Figure 3 and Table 2).
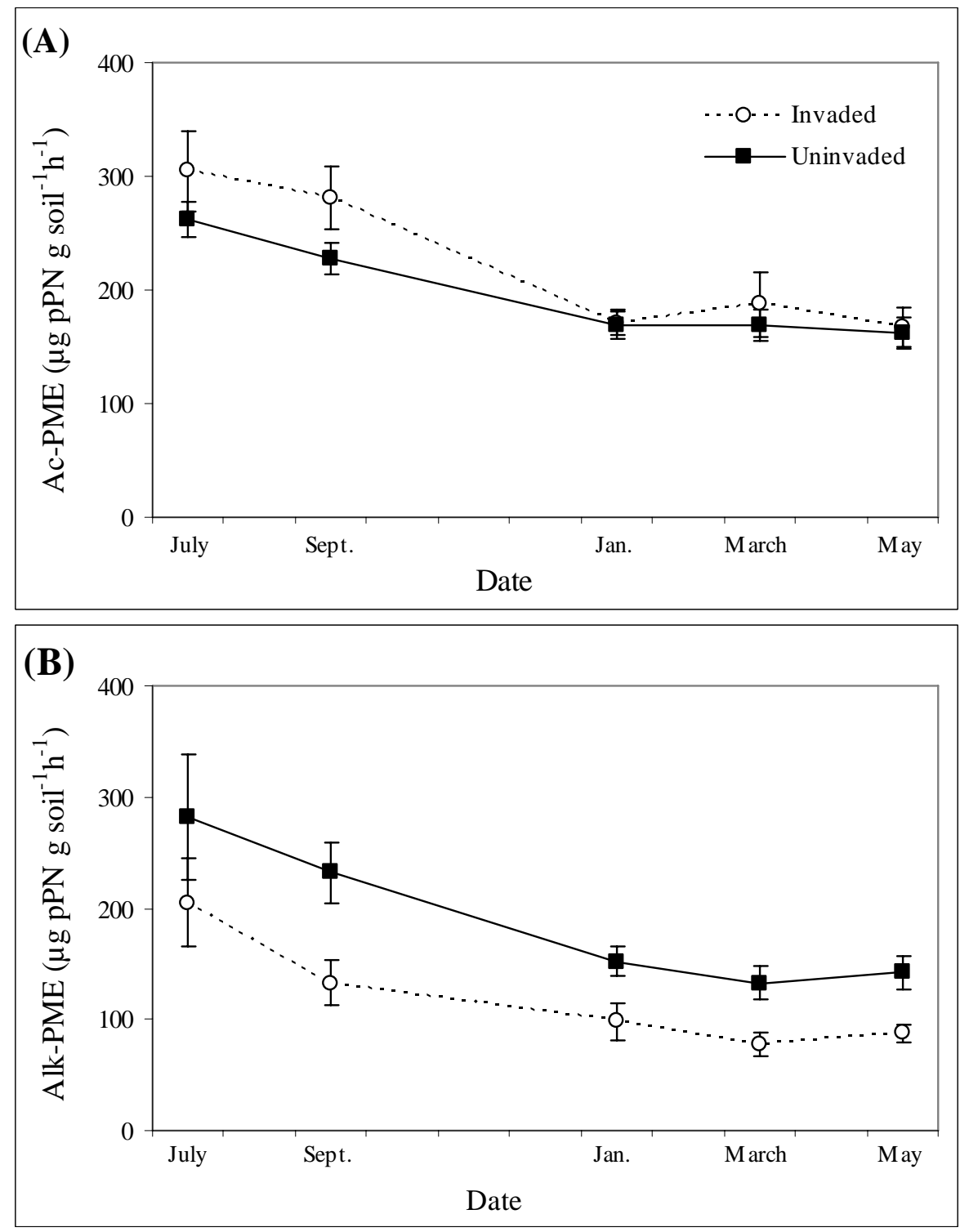

Figure 3: Seasonal variation of soil phosphomonesterase (PME) activity in plots invaded by early Goldenrod and adjacent, uninvaded plots. (A) Ac-PME, (B) Alk-PME. Means ( $\mathrm{n}=6)$ and standard deviations. 


\subsubsection{Microbial P}

$\mathrm{P}$ immobilized in microbial biomass was highest in September and decreased until the end of the winter, where it was close to zero, and then increased again in the spring. The date effect was significant (Table 2). There was no significant difference between invaded and uninvaded stands (Figure 4 and Table 2).

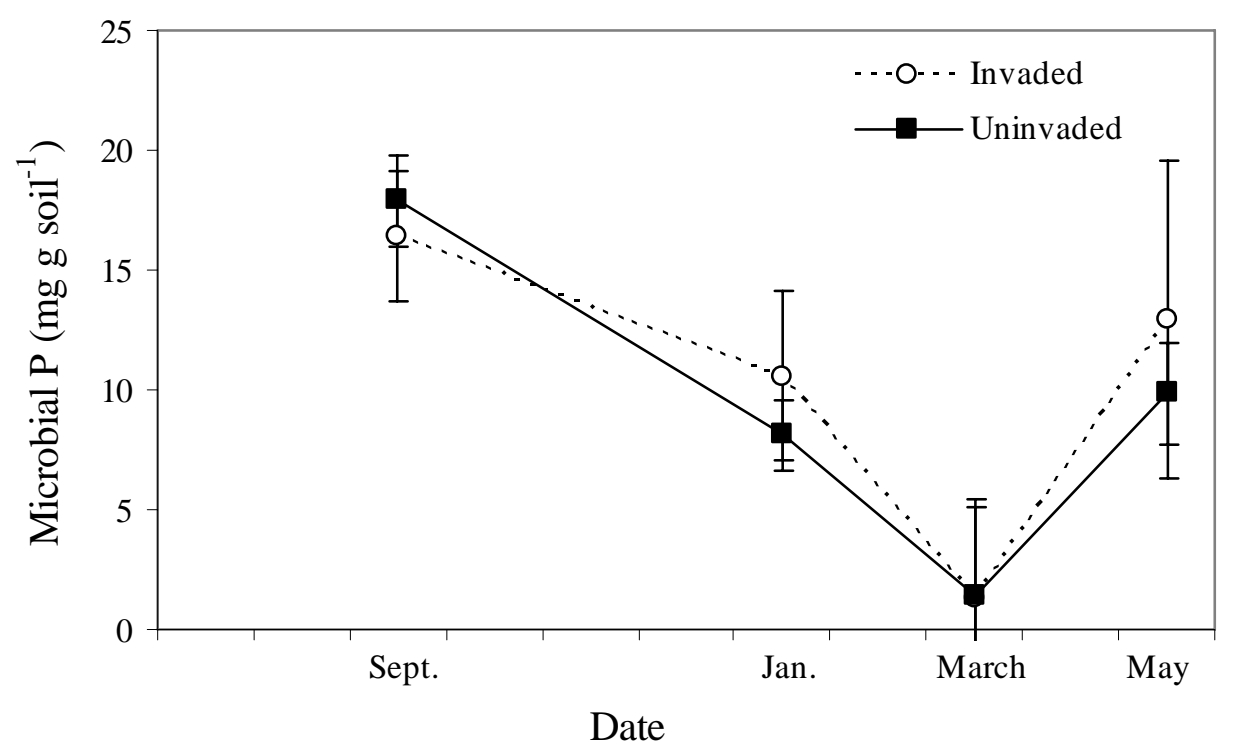

Figure 4: Seasonal variation of soil microbial P $(0-10 \mathrm{~cm})$ in plots invaded by early Goldenrod and adjacent, uninvaded plots. Means $(n=6)$ and standard deviations.

\section{$3.2 P$ concentrations and stocks in plants}

\subsubsection{Aboveground organs}

Seasonal variation in aboveground biomass, P concentration and stocks was much larger for Solidago compared to uninvaded stands, which resulted in highly significant date $\mathrm{x}$ invasion interaction for all these parameters. Aboveground biomass (including litter) of uninvaded plots showed little seasonal variation, ranging from $600 \mathrm{~g} \mathrm{~m}^{-2}$ in summer to $500 \mathrm{~g} \mathrm{~m}^{-2}$ in winter (Figure 5). In contrast, aboveground biomass of Solidago showed a marked seasonal pattern, with highest values in August $\left(1700 \mathrm{~g} \mathrm{~m}^{-2}\right)$ and lowest values in winter (800 $\mathrm{g} \mathrm{m}^{-2}$; that was close to zero if litter was not considered). When litter was pooled with living parts as presented in Figure 5, phytomass was consistently higher in invaded compared to uninvaded stands. 

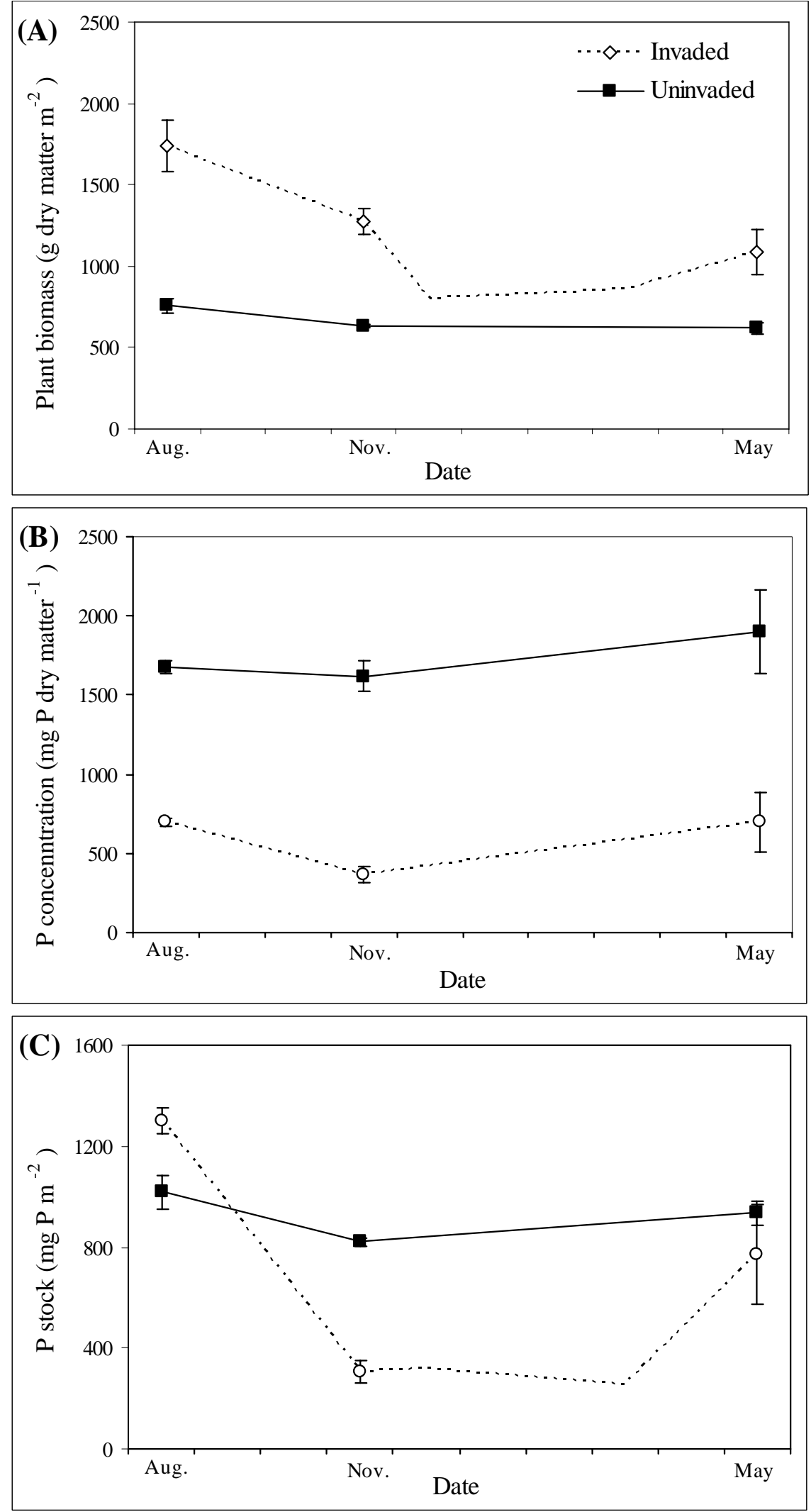

Figure 5: Seasonal variation of standing biomass (A), P concentration (B) and P pools in standing biomass (C) in plots invaded by early Goldenrod and adjacent, uninvaded plots. Litter and dead shoots of Solidago included. Error bars are standard deviations. 
Average concentrations of $\mathrm{P}$ in aboveground biomass (including litter) were lowest in winter and highest in spring in both types of stands. They were 2- to 4-fold higher in uninvaded than in invaded stands (annual mean, uninvaded: $1733 \mathrm{mg} \mathrm{P} \mathrm{kg} \mathrm{dry} \mathrm{matter}{ }^{-1}$, invaded: $586 \mathrm{mg} \mathrm{P}$ kg dry matter ${ }^{-1}$ ). Total P stocks in aboveground biomass plus litter showed a marked seasonal pattern, most strikingly so for Solidago, with the highest values in summer, the lowest values in November and intermediate values in spring. Invaded stands had lower aboveground stocks of $\mathrm{P}$ in autumn and winter and higher stocks in August, compared to uninvaded stands.

$\mathrm{P}$ concentrations and stocks in stems and leaves of Solidago are presented in Table 3. P concentration of leaves was 2- to 4-fold higher than in stems. For both types of organs, P concentrations were highest in May and decreased steadily to November. Resorption efficiency, calculated as the ratio of $\mathrm{P}$ concentration in November to $\mathrm{P}$ concentration in August was $67 \%$ for stems and $39 \%$ for leaves. At the peak of total aboveground biomass, living biomass of Solidago consisted of 32\% leaves and 68\% stems. Figures for the uninvaded vegetation are not available, due to the difficulty to separate leaves from stems and senescing organs from living organs in grasses.

Table 3: Mass, $\mathrm{P}$ concentration and P stocks of stems and leaves of Solidago gigantea at three dates.

\begin{tabular}{ccccc}
\hline \multirow{2}{*}{ August } & Stems & $\begin{array}{c}\text { Mass } \\
\left(\mathrm{g} \mathrm{m}^{-2}\right)\end{array}$ & $\begin{array}{c}\text { P concentration } \\
\left(\mathrm{mg} \mathrm{kg} \mathrm{soil}^{-1}\right)\end{array}$ & $\begin{array}{c}\mathrm{P} \mathrm{stock}^{-2} \\
\left(\mathrm{mg} \mathrm{m}^{-2}\right)\end{array}$ \\
& Leaves & 350 & 680 & 510 \\
November & Stems & 49 & 1585 & 550 \\
& Leaves & 20 & 220 & 110 \\
May & Stems & 100 & 960 & 20 \\
& leaves & 90 & 1390 & 150 \\
& & & 4195 & 400 \\
\hline
\end{tabular}

\subsubsection{Belowground organs}

Biomass of belowground organs was roughly similar for both types of stands in August (1156-1399 $\mathrm{g} \mathrm{m}^{-2}$ ) and steadily increased from August to November, most strikingly so for Solidago. In November, biomass of belowground organs of Solidago was ca. 35\% higher compared to the control and this difference was significant $(P<0.01)$. 
Concentrations of $\mathrm{P}$ in belowground organs were not significantly different for the two types of plots (Table 4, $P>0.05$ ). For Solidago, it increased from August to November (1400 to $1921 \mathrm{mg} \mathrm{P} \mathrm{kg}^{-1}$ ) but the difference was not significant due probably to low sample size $(n=4)$. P stocks in belowground organs increased from August to November in both types of stands. In August, they were similar for both types of stands, while P stocks were much higher in Solidago compared to the control in November (Table 4, 5426 vs. $3271 \mathrm{mg} \mathrm{P} \mathrm{m}^{-2}$ ).

Table 4: Seasonal variation of average $(n=4)$ belowground biomass, P concentration and stock in roots from plots invaded by early Goldenrod and adjacent, uninvaded plots.

\begin{tabular}{|c|c|c|c|c|c|c|}
\hline & \multicolumn{2}{|c|}{$\begin{array}{c}\text { Biomass } \\
\text { (g dry matter } \mathrm{m}^{-2} \text { ) } \\
\end{array}$} & \multicolumn{2}{|c|}{$\begin{array}{c}\text { P concentration } \\
\left(\mathrm{mg} \mathrm{P} \mathrm{kg} \mathrm{dry} \mathrm{matter}^{-1}\right) \\
\end{array}$} & \multicolumn{2}{|c|}{$\begin{array}{c}\text { P stock } \\
\left(\mathrm{mg} \mathrm{P} \mathrm{m}^{-2}\right)\end{array}$} \\
\hline & Aug. & Nov. & Aug. & Nov. & Aug. & Nov. \\
\hline Uninvaded & 1156 & 1822. & 1720 & 1811 & 1909 & 3271 \\
\hline Invaded & 1399 & 2813 & 1400. & 1921 & 1926 & 5426 \\
\hline$P$ level $^{\mathrm{a}}$ & ns & $* *$ & ns & ns & ns & $*$ \\
\hline
\end{tabular}

${ }^{\mathrm{a}}$ Statistical significance for $t$-tests performed for a parameter within a date between uninvaded and invaded plots: ns, not significant; ** $P<0.01$; ${ }^{*} P<0.05$

\section{Discussion}

A striking result is the finding of systematic differences in $\mathrm{P}$ availability and $\mathrm{pH}$ between topsoil of closely adjacent invaded and uninvaded plots. Our sampling protocol was designed to reduce the possibility of pre-existing differences in soil conditions between plots. Thus, within site homogeneity of soil texture and soil profile was checked. Moreover, S. gigantea is still expanding in this site and uninvaded plots were located close to the front of expansion of invaded stands. Furthermore, S. gigantea occurs over a wide range of soil conditions (Weber and Jakobs, 2005). In Belgium, the following variation ranges were observed for Solidago-invaded sites: $\mathrm{pH} 5.9$ to 7.2, resin-Pi: 25.6 to $91.5 \mathrm{mg} \mathrm{P} \mathrm{kg}^{-1}$ (measured on air-dried soil samples), bicarb-Pi: 21.7$81.0 \mathrm{mg} \mathrm{Pi} / \mathrm{kg}$, carbon: 1.5 to $6.4 \%$ and clay: 2.4 to $17.0 \%$ (Chapuis-Lardy et al., 2006). It is thus unlikely that fine-scale variation in soil chemistry is governing the present distribution of S. gigantea within our study site. We believe that plant-driven variation 
is the most likely mechanism explaining the observed spatial variation in soil conditions.

We have found increased concentrations of several forms of inorganic P (Resin-Pi, Bicarb-Pi and $\mathrm{NaOH}-\mathrm{Pi}$ ) in invaded stands. All these fractions are considered as bioavailable at more or less short term (Mallarino and Atia, 2005; Scott and Condron, 2003; Spears et al., 2001). Increased availability of phosphorus under Solidago might be explained by one or a combination of the following mechanisms: nutrient uplift, enhanced mineralization, altered turn over of microbial community, a shift in the geochemical equilibria controlling $\mathrm{P}$ availability and differences in the flux rates of $\mathrm{P}$ through the plant community. These hypotheses will be addressed in turn.

\subsection{Nutrient uplift}

Plant can increase availability of nutrients in topsoil by the mechanism of nutrient uplift (Jobbágy and Jackson, 2004), i.e. net displacement of nutrients from deep layers to topsoil. This was shown for the alien invasive crucifer Lepidium latifolium (Blank and Young, 2002). However, S. gigantea does not have deeper rooting depth compared to the resident vegetation (pers. obs.). Moreover, nutrient uplift cannot be invoked to explain increased concentrations of a single nutrient.

\subsection{Organic P mineralization}

Our results show a slight, non significant increase of acid PME and a significant decrease of alkaline PME. These observations do not roughly support the hypothesis that increased concentrations of inorganic $\mathrm{Pi}$ in invaded stands would be due to enhanced mineralization by phosphomonoesterases. In spite of the large number of published studies, the relationships between PME activity and the rate of organic $\mathrm{P}$ mineralization remain obscure (Chen et al., 2002). Negative correlations between spatial variation in availability of inorganic P and PME activity were sometimes documented (Chen et al., 2003). Higher concentrations of inorganic $\mathrm{P}$ in soils have shown to reduce phosphatase activity by feedback inhibition (Tabatabai, 1982; Harrison, 1983). PME activity is also very susceptible to pH (Kang and Freeman, 1999; Dick et al., 2000) and decreased alk-PME activity in invaded stands might be related to lower $\mathrm{pH}$. Another 
hypothesis is the presence of functionally different organisms producing alkaline phosphatase in both plots (invaded vs. uninvaded). We did not characterize soil fungi that can be effective producers of alkaline PME (Tarafdar and Chhonkar, 1979). Moreover, phosphomonoesterases are not the sole enzymes involved in P mineralization (Tabatabai, 1982) and hydrolysis of complex organic $\mathrm{P}$ compounds may be more limiting (Nakas et al., 1987). A hypothesis could be the presence of other phosphate releasing enzymes in the litter such as phosphodiesterases. Turner et al. (2002a, b) showed that only small amounts of both organic and condensed P compounds, in soil solution, were hydrolysed by phosphomonoesterases alone, whilst a combination of phosphomonoesterases and phosphodiesterases hydrolysed much greater proportions. Moreover, they have shown that diester forms of soil organic $\mathrm{P}$ were more labile and more readily mineralised than monoesters, and thus play an important role in the transformations of $\mathrm{P}$.

Similar topsoil carbon concentrations in both kinds of plots, in spite of higher primary productivity both above- and belowground in invaded stands, still point to higher decomposition rates in invaded stands. Litter decomposition rate is strongly influenced by the $\mathrm{C} / \mathrm{N}$ and $\mathrm{C} / \mathrm{P}$ ratio (Kwabiah et al., 2003a, b). Dead leaves of Solidago have higher concentrations of $\mathrm{P}$ than aboveground biomass of the control, (960 mg P g dry matter $^{-1}$ vs. 480 mg $\mathrm{P}$ g dry matter ${ }^{-1}$, respectively). It is well known that differences in litter quality can influence soil P status. Thus Nziguheba et al. (1998) have observed increased resin-Pi, Bicarb-Pi and NaOH-Pi in the soil after addition of leaf litter of the Asteraceae Tithonia diversifolia, and no effect of leaf litter of maize.

\subsection{Microbial immobilization}

Microbial phosphorus fraction was not different between invaded and uninvaded stands. Seasonal variations allow calculating the turnover rate of this fraction (turnover $=$ annual mean of microbial P / cumulated losses of microbial P) (Chen et al., 2003). Turnover of microbial $\mathrm{P}$ is $1.76 \mathrm{y}^{-1}$ and $1.47 \mathrm{y}^{-1}$ in control and invaded plots, respectively. Thus, increased available $\mathrm{P}$ fraction cannot be accounted for by higher turnover of microbial P. This conclusion must be taken with caution, however, because of the low sampling frequency of microbial $\mathrm{P}$ in our study. Differences in the composition of the bacteria and fungi communities might still be involved. 


\subsection{Influence on geochemical equilibria}

Bioavailability of soil inorganic $P$ is strongly affected by root-induced chemical changes (Hinsinger, 2001). Stands invaded by S. gigantea were found to have decreased $\mathrm{pH}$ values (5.9 vs. 6.5) $\mathrm{pH}$ is indeed one of the most important parameters determining adsorption/desorption equilibria of phosphate in soils (Hinsinger, 2001). It is quite possible that the observed half a unit decrease of $\mathrm{pH}$ might favor solubility of mineral $\mathrm{P}$ compounds as suggested by Chapuis-Lardy et al. (2006) in a former study that includes our study site. Decreased $\mathrm{pH}$ was also invoked as a possible mechanism for the increased P availability under the exotic invasive Lepidium latifolium (Blank and Young, 2002). Both increased and decreased $\mathrm{pH}$ under the canopy of invasive plants were documented (see Ehrenfeld (2003) for a review). Enhanced nitrification was proposed as a likely explanation for decreased $\mathrm{pH}$ under the canopy of the invasive Berberis thunbergii and Microstegium vimineum in North American deciduous forests (Ehrenfeld et al., 2001; Ehrenfeld, 2003). Other possible mechanisms include shifts in nitrogen nutrition from predominantly nitrate- to ammonium-based, production of organic acids by roots (Hinsinger et al., 2003; Vanderhoeven et al., 2006). Acidification may enable Solidago to obtain phosphorus from fractions that are little available to the resident vegetation. Interestingly, the formation of mycorrhizae was largely reported in the literature for most of the native plants (e.g. Harley and Harley, 1987) as well as for Solidago canadensis, which is also invasive in Europe (Jin et al., 2004). The ability in S. Canadensis to form mycorrhizae with different Glomus species was invoked to explain the ability of the species to colonize newly reclaimed habitats (Jin et al., 2004). More effective secretion of organic acids by roots or mycorrhizae might increase availability of P under Solidago (Frossard et al., 1995; Geelhoed et al., 1999).

\subsection{Nutrient fluxes in plants}

Solidago stands have much higher standing biomass in summer compared to control plots. However, due to low concentrations of $\mathrm{P}$ in stems $\left(680 \mathrm{mg} \mathrm{kg}\right.$ dry matter ${ }^{-1}$ compared to $1680 \mathrm{mg} \mathrm{kg}$ dry matter $^{-1}$ in the control), phosphorus stocks in living aboveground biomass are roughly similar between invaded and uninvaded plots (1000 mg $\mathrm{P} \mathrm{m}{ }^{-2}$ ). This result must be taken with caution, however, because the difference Invaded vs. Uninvaded in aboveground biomass apparently varies from year to year due 
to changes in control biomass. Thus, in the year 2003, aboveground biomass in the control plots was $250 \mathrm{~g} \mathrm{~m}^{-2}$, i.e. more than two times as much as in 2004 (ChapuisLardy et al., 2006). Based on the $\mathrm{P}$ concentration difference between August and November, resorption of $\mathrm{P}$ from senescing shoots of Solidago can be estimated as $c a$. $550 \mathrm{mg} \mathrm{P} \mathrm{m}^{-2}$. Thus, resorption efficiency is $52 \%$, i.e. close to the average value for herbaceous dicots (Aerts, 1996). Resorption could not be measured in the resident vegetation, because aboveground biomass samples comprised both living and senesced leaves. Using the average resorption efficiency for graminoids species (70\%) as reported by Aerts (1996) resorption flux can be estimated as $700 \mathrm{mg} \mathrm{P} \mathrm{m}^{-2}$. Thus, annual loss rate of $\mathrm{P}$ by aboveground organs might be somewhat larger in Solidago patches compared to the control (ca. $500 \mathrm{mg} \mathrm{P} \mathrm{m}^{-2}$ vs. $300 \mathrm{mg} \mathrm{P} \mathrm{m}^{-2}$ ). However, this difference cannot account for the difference in the stock of $\mathrm{P}$ in the $\mathrm{NaOH}-\mathrm{Pi}$ fraction (2400 mg $\mathrm{P}$ $\left.\mathrm{m}^{-2}\right)$.

Phosphorus stocks in belowground organs of Solidago show a more than two-fold increase from August to November, mainly due to increased biomass. The autumnal increase in $\mathrm{P}$ stocks in belowground organs can be calculated as $3500 \mathrm{mg} \mathrm{P} \mathrm{m}^{-2}$ in Solidago and $1300 \mathrm{mg} \mathrm{P} \mathrm{m}^{-2}$ in the control. Resorption of $\mathrm{P}$ from aboveground organs

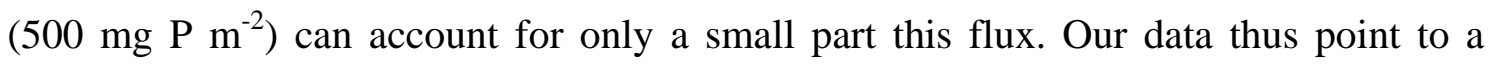
massive root uptake of $\mathrm{P}$ by Solidago in autumn, probably coupled to fine root production. This uptake is far in excess of $\mathrm{P}$ requirements for aboveground organs in subsequent year in Solidago, which were calculated as $1300 \mathrm{mg} \mathrm{P} \mathrm{m}^{-2}$. Although belowground biomass was not measured in the spring, it is reasonable to assume a steady state situation for biomass from year to year. It thus appears that most of the $\mathrm{P}$ that is absorbed and stored in belowground organs in autumn will be lost before next summer in belowground litter. Nutrient resorption from senescing roots is usually low (Chapin, 1980). Fast nutrient leaching and mineralization was already reported for roots, suggesting that root may play a major role in the cycling of nutrients (Scheffer and Aerts, 2000). P is easily released from dying roots (Eason and Newman, 1990) and quick release of $\mathrm{P}$ from decomposing roots was invoked as a possible mechanism of $\mathrm{P}$ soil enrichment (Campbell et al., 1993).

Interestingly, the difference in $\mathrm{P}$ stock in belowground organs in autumn is quite similar to the difference in the stock of $\mathrm{NaOH}-\mathrm{Pi}$ in the soil (2400 $\mathrm{mg} \mathrm{P} \mathrm{m}^{-2}$ ). Intense mobilization of $\mathrm{P}$ by Solidago roots in autumn and restitution of easily mineralisable root debris in next spring may well contribute to the higher availability of $\mathrm{P}$ observed in invaded plots in this study. 
Invasion by Early Goldenrod alters phosphorus fractions, pools and fluxes in the study site. Higher concentrations of bioavailable phosphorus in the topsoil might be due to a combination of enhanced $\mathrm{P}$ turnover rates in belowground organs, and rhizosphere acidification. It would be interesting to test if enhanced $\mathrm{P}$ availability results in a positive feed-back, i.e. an aggravation of the competitive superiority of Early Goldenrod over the resident vegetation.

Acknowledgements The present study was conducted in collaboration with the project INPLANBEL (Invasive Plants in Belgium: Patterns, Processes and Monitoring) funded by the Belgian Science Policy.

\section{References}

Aerts, $R$. (1996): Nutrient resorption from senescing leaves of perennials: are there general patterns? J. Ecol. 84, 597-608.

Bartlett, R., James, B. (1980): Studying dried, stored soil samples - some pitfalls. Soil Sci. Soc. Amer. J. 44, 721-724.

Blank, R. R., Young, J. A. (2002): Influence of the exotic invasive crucifer, Lepidium latifolium, on soil properties and elemental cycling. Soil Sci. 167, 821-829

Bowman, R. A., Cole, C. V. (1978): An exploratory method for fractionation of organic phosphorus from grassland soils. Soil Sci. 125, 95-101.

Brookes, P. C., Powlson, D. S., Jenkinson, D. S. (1982): Measurement of microbial biomass phosphorus in soil. Soil Biol. Biochem. 14, 319-329.

Campbell, C. A., Lafond, G. P., Biederbeck, V. O., Winkleman, G. E. (1993): Influence of legumes and fertilization on deep distribution of available phosphorus (Olsen-Pi) in a thin black chernozomic soil. Can. J. Soil Sci. 73, 555-565.

Chapin, F. S. (1980): The mineral nutrition of wild plants. Annu. Rev. Ecol. Syst. 11, 233-260.

Chapuis-Lardy, L., Vanderhoeven, S., Dassonville, N., Koutika, L. S., Meerts, P (2006). Effects of the invasive plant Solidago gigantea on soil phosphorus. Biol. Fertil. Soils, 42, 481-489. 
Chen, C. R., Condron, L. M., Davis, M. R., Sherlock, R. R. (2002): Phosphorus dynamics in the rhizosphere of perennial ryegrass (Lolium perenne L.) and radiata pine (Pinus radiata D. Don.). Soil Biol. Biochem. 34; 487-499.

Chen, C. R., Condron, L. M., Davis, M. R., Sherlock, R. R. (2003). Seasonal changes in soil phosphorus and associated microbial properties under adjacent grassland and forest in New Zealand. Forest Ecol. Manag. 177, 539-557.

Chen $H$. (2003). Phosphatase activity and P fractions in soils of an 18-year-old chinese fir (Cunninghamia lanceolata) plantation. Forest Ecol. Manag. 178, 301-310.

Dick, W. A., Cheng, L., Wang, P. (2000): Soil acid and alkaline phosphatase activity as pH adjustment indicators. Soil Biol. Biochem. 32, 1915-1919.

Eason W. R., Newman E. I. (1990): Rapid loss of phosphorus from dying ryegrass roots: the chemical components involved. Oecologia 82, 432-436

Ehrenfeld, J. G. (2003): Effect of exotic plant invasions on soil nutrient cycling processes. Ecosystems 6, 503-523.

Ehrenfeld, J. G., Kourtev, P., Huang, W. (2001): Changes in soil functions following invasions of exotic understory plant in deciduous forests. Ecol. Appl. 11, 1287-1300.

Evans, R. D., Rimer, R., Sperry, L., Belnap, J. (2001): Exotic plant invasion alters nitrogen dynamics in an arid grassland. Ecol. Appl. 11, 1301-1310.

FAO - UNESCO (1990): Soil map of the world, Revised legend. World Soil Ressources Report 60. FAO, Rome, p. 119.

Frossard, E., Brossard, M., Hedley, M. J., Metherell, A. (1995): Reactions controlling the cycling of $\mathrm{P}$ in soils, in Tiessen H.: SCOPE 54, Phosphorus in the global environment, J. Wiley \& Sons Ltd., Chichester, pp. 107-137.

Geelhoed, J. S., Van Riemsdijk, W. H., Findenegg, G. R. (1999): Simulation of the effect of citrate exudation from roots on the plant availability of phosphate adsorbed on goethite. Eur. J. Soil Sci. 50, 379-390.

Grierson, P. F., Adams, M. A. (2000): Plant species affect acid phosphatase, ergosterol and microbial P in a Jarrah (Eucalyptus marginata Donn ex Sm.) forest in southwestern Australia. Soil Biol. Biochem. 32, 1817-1827.

Güsewell, S., Zuberbuhler, N., Clerc, C. (2005): Distribution and functional traits of Solidago gigantea in a Swiss lakeshore wetland. Bot. Helv. 115, 63-75.

Harley, J. L., Harley, E. L. (1987). A check-list of mycorrhiza in the British flora. New Phytol. 105 (2), 1-102.

Harrison, A. F. (1983): Relationship between intensity of phosphatase activity and physic-chemical properties in the woodland soils. Soil Biol. Biochem. 15, 93-99. 
Hinsinger, P. (2001): Bioavailability of soil inorganic P in the rhizosphere as affected by root-induced chemical changes: a review. Plant Soil 237, 173-195.

Hinsinger, P., Plassard, C., Tang, C., Jaillard, B. (2003): Origins of root-mediated pH changes in the rhizosphere and their responses to environmental constraints: A review. Plant Soil 248, 43-59.

Hooper, D. U., Vitousek, P. M. (1998): Effects of plant composition and diversity on nutrient cycling. Ecol. Monogr. 68 , 121-149.

Jakobs, G., Weber, E., Edwards, P. J. (2004): Introduced plants of the invasive Solidago gigantea (Asteraceae) are larger and grow denser than cospecifics in the native range. Divers. Distrib. 10, 11-19.

Jin, L., Gu, Y.G., Xiao, M., Chen, J.K., Li, B. (2004): The history of Solidago canadensis invasion and the development of its mycorrhizal associations in newlyreclaimed land. Funct. Plant Biol. 31, 979-986.

Jobbágy, E. G., Jackson R. B. (2004): The uplift of soil nutrients by plants: Biogeochemical consequences across scales. Ecology 85, 2380-2389

John, M. K. (1970): Colorimetric determination of phosphorus in soil and plant materials with ascorbic acid. Soil Sci. 109,214-220.

Kang, H., Freeman, C. (1999): Phosphatase and arylsulphatase activities in wetland soils: annual variation and controlling factors. Soil Biol. Biochem. 31, 449-454.

Kouno, K., Tuchiya, Y., Ando, T. (1995): Measurement of soil microbial biomass phosphorus by an anion exchange membrane method. Soil Biol. Biochem. 27, 13531357.

Kourtev, P. S., Ehrenfeld, J. G., Huang, W. Z. (2002): Enzyme activities during litter decomposition of two exotic and two native plant species in hardwood forests of New Jersey. Soil Biol. Biochem. 34, 1207-1218.

Krämer, S., Green D. M. (2000): Acid and alkaline phosphatase dynamics and their relationship to soil microclimate in a semiarid woodland. Soil Biol. Biochem. 32, 179-188.

Kwabiah, A. B., Stoskopf, N. C., Palm, C. A., Voroney, R. P. (2003)a: Soil P availability as affected by the chemical composition of plant materials : implications for Plimiting agriculture in tropical Africa. Agric. Ecosyst. Environ. 100, 53-61.

Kwabiah, A. B., Stoskopf, N. C., Palm, C. A., Voroney, R. P., Rao, M. R., Gacheru, E. (2003)b: Phosphorus availability and maize response to organic and inorganic fertilizer inputs in a short term study in western Kenya. Agric. Ecosyst. Environ. 95, 49-59. 
Mallarino, A. P., Atia, A. M. (2005): Correlation of a resin membrane soil phosphorus test with corn yield and routine soil tests. Soil Sci. Soc. Amer. J. 69, 266-272.

McLaughlin, M. J., Alston, A. M. (1986): Measurement of phosphorus in the soil microbial biomass: a modified procedure for field soils. Soil Biol. Biochem. 18, 437443.

Nakas, J. P., Gould, W. D., Klein, D. A. (1987): Origin and expression of phosphatase activity in a semi-arid grassland soil. Soil Biol. Biochem. 19, 13-18.

Nziguheba, G., Palm, C. A., Buresh, R. J., Smithson, P. C. (1998): Soil phosphorus fractions and adsorption as affected by organic and inorganic sources. Plant Soil 198, 159-168.

Olsen, S. R., Sommers, L. E. (1982): Phosphorus in Methods of Soil Analysis, in Page, A. L., Miller, R. H., Keeney, D. R.: Methods of Soil Analysis, Part 2, Chemical and Microbiological Properties. American Society of Agronomy, Madison, WI., pp. 421422.

Scheffer, R. A., Aerts, R. (2000): Root decomposition and soil nutrient and carbon cycling in two temperate fen ecosystems. Oikos 91: 541-549.

Scott, J. T., Condron, L. M. (2003): Dynamics and availability of phosphorus in the rhizosphere of a temperate silvopastoral system. Biol. Fertil. Soils 39, 65-73.

Spears, J. D. H., Lajtha, K., Caldwell, B. A., Pennington, S. B., Vanderbilt, K. (2001): Species effects of Ceanothus velutinus versus Pseudotsuga menziesii, Douglas-fir, on soil phosphorus and nitrogen properties in the Oregon cascades. Forest Ecol. Manag. 149, 205-216.

Tabatabai, M. A. (1982): Soil enzymes, in Page, A. L., Miller, R. H., Keeney, D. R.: Methods of Soil Analysis, Part 2, Chemical and Microbiological Properties. American Society of Agronomy, Madison, WI., pp. 903-948.

Tarafdar, J. C., Chhonkar, P. K. (1979): Phosphatase production by microorganisms isolated from diverse types of soils. Zentralbl. Bakteriol. Naturwiss. 134, 119-24.

Tiessen, H., Moir, J. O. (1993): Characterization of available P by sequential extraction, in Carter, M. R.: Soil sampling and methods of analysis. Lewis Publishers, Boca Raton, FL., pp. 75-86.

Turner, B. L., McKelvie, I. D., Haygarth, P. M. (2002)a: Characterisation of waterextractable soil organic phosphorus by phosphatase hydrolysis. Soil Biol. Biochem. 34, 27-35. 
Turner, B. L., Baxter, R., Whitton, B. A. (2002)b: Seasonal phosphatase activity in three characteristic soils of the English uplands polluted by log-term atmospheric nitrogen deposition. Environ. Pollut. 120, 313-317.

Tyser, R. W., Key, C. H. (1988): Spotted knapweed in natural area fescue grasslands: an ecological assessment. Northwest Sci. 62, 151-160

Vanderhoeven S., Dassonville N., Chapuis-Lardy L., Hayer M., Meerts P (2006): Impact of the invasive Solidago gigantea on primary productivity and topsoil chemistry. Plant Soil, 286, 259-268.

Vitousek, P. M. (1990): Biological invasions and ecosystem processes: towards an integration of population biology and ecosystem studies. Oikos 57, 7-13.

Vitousek, P. M., Walker, L. R., Whiteaker, L. D., Mueller-Dombois, D., Matson, P. A. (1987): Biological invasion by Myrica faya alters ecosystem development in Hawaii. Science 238, 802-804.

Weber, E., Jakobs, G. (2005): Biological flora of Central Europe: Solidago gigantea Aiton. Flora 200, 109-118.

Witowski, E. T. F., Mitchell, D.T. (1987): Variations in soil phosphorus in the fynbos biome, South Africa. J. Ecol. 75, 1159-1171. 